\title{
Exploring for Plants in Southern Tibet
}

\author{
By Capt. F. Kingdon-Ward
}

$\mathrm{H}^{\mathrm{A}}$ AVING left Tezpur, an ancient Assamese town, on the right bank of the Brahmaputra, towards the end of April last year, and crossed the outer range of the Assam Himalaya by the Pankim La at $10,000 \mathrm{ft}$., I arrived in the dry river valleys early in May. There is only one possible route over the great range in a distance of three hundred miles, between the Bhutan frontier and the gorge of the Brahmaputra; east of the Bhareli River savage tribes-Daflas, Akas, Abors and others-bar the way. Travelling leisurely northwards, the Tibetan frontier was crossed by the Se La (14,000 ft.) early in June and Mönyul was reached. The rainy season had begun, and this part of the journey, over a series of moderately high passes, was cold and wet.

Already the alpine flowers were in full bloom. Two dozen species of Rhododendron were collected, several of them new to science, and half of them new to Assam. Several Chinese species appeared, still further confirming the unity of the eastern Himalayan and Chinese alpine floras. Certain species of Primula occurred in vast numbers, painting the meadows bright colours; among them the mauve $P$. atrodentata, $P$. Roylei and $P$. Gamblii. The last two have each two distinct colour forms, yellow and blueviolet.

In the middle of June, I crossed the snow range by two passes both at a height of more than $17,000 \mathrm{ft}$. and reached the dry Tibetan plateau at the head. waters of the Subansiri. Here the flora was entirely different. There is no forest, but a few trees grow in the villages, where the crops are irrigated. Along the irrigation channels a charming bi-coloured 'sibirica' iris grew in masses. The dry rocky slopes are dotted with thorny bushes and scattered herbaceous plants. To the west, the country grows more and more arid, but eastwards the forest reappears even on the north slopes of the Himalayan range itself. So I turned north-eastwards, and crossing two more ranges at $16,000 \mathrm{ft}$. altitude, reached the sacred valley of Tsari. Incredible numbers of primulas-chiefly a yellow-flowered form of $P$. alpicola-filled the meadows. Many endemic species grow in this country, where the Tibetan rivers leave the plateau to pierce the Himalaya; for example, Meconopsis argemonantha (the only known white-flowered species), Primula Cawdoriana, Rhododendron hirtipes and R. temoense, Cyananthus Wardii, Lilium Wardii and others.

From Tsari, the next range to the north was crossed, and I travelled for eight consecutive days through quite unknown country. The high ranges were all well forested now with conifer forest above and mixed forest below. As the Tsangpo was approached, $P$ inus tabuloeformis became the dominant tree (10,000-11,000 ft.). The Tsangpo was reached at Lilung, thus linking up the new route with my route of 1924 . I turned eastwards down the Tsangpo valley and on July 22 reached Tsela Dzong. I was now well into the river gorge country, at the wettest season of the year. Continuing northwards, Tongkyuk was reached, and on August 1 I set out to explore the great unknown range of snow peaks which I had reason to believe stretched east and west some thirty or forty miles north of the Tsangpo.

For the first time for two months I found myself below 10,000 ft. The Yigrong River was explored to its source; it was followed westwards through a series of magnificent wooded gorges for eighteen days. At first the forest consisted largely of broad-leafed trees, including oaks, laurels, maples and birch, but gradually conifers increased, chiefly $P$ inus excelsa, P. tabulaeformis and Tsuga Brunoniana. There were snow peaks and glaciers on both sides of the river, but the bulk of the great snow range lay to the south, where there were peaks probably $25,000 \mathrm{ft}$. high. The source of the Yigrong is in the largest glaciers known north of the Tsangpo.

Recrossing the range by a high pass, I reached the Gyalam (that is, the Lhasa-China road) at Gyamda, about 120 miles east of Lhasa. The country here is much drier again; there is far less forest, and fewer species of trees. It was now the end of August, the height of summer there, and numbers of beautiful flowers were in bloom, including the robust and handsome Salvia Wardii, the half shrubby Draco. cephalum Hemslyanum, with large sapphire blue flowers, Codonopsis convolvulacea and species of Adenophora.

Continuing westwards, the Lhasa road was followed for two days, and then I turned southwards to cross the unknown country which separated me from the Tsangpo. Crossing the range at 17,000 ft., I reached the Tsangpo sixty miles west of Lilung. The blueflowered Onosma Waddellii was in fruit here, also the delightful sand dune plant Oxytropis sericopetala. A different route back to the headwaters of the Subansiri was followed, and plants and seeds were collected.

Finally, in October, I once more crossed the great Himalayan range, and varying my route, covered a good deal of botanically unknown country. One of my last finds was a charming new species of slipper orchid (Cypripedium). I arrived at the Assam plain again on the last day of October, after a journey of six months.

During that time I had travelled about 1,500 miles, crossed more than twenty passes between $15,000 \mathrm{ft}$. and 17,000 ft., and explored 600 miles of unknown routes. Many hundreds of species of plants had been collected, including a number of new species, and seed of some of the best for English gardens was obtained. The great snow range north of the Tsangpo was definitely located and followed for a hundred miles.

Botanically, it was possible to recognise three main divisions of the Tibetan flora, which correspond fairly closely with the three stages in the degradation of the plateau. But the observations and collections also emphasise the unity of the Tibetan flora as a whole, and its close similarity to that of western China and the Himalaya. The Tibetan flora is not of central Asian affinity; Tibet, western China and the entire Himalaya form a phytogeographic whole, which may be distinguished by the term 'Sino. himalayan'. 